\title{
DOMINASI IBU DALAM PERAN PENGASUHAN ANAK DIBENDA KEREP CIREBON
}

\author{
Lutfatulatifah $^{*}$ \\ IAIN SYEKH NURJATI CIREBON
}

uul@syekhnurjati.ac.id

- Received: 25 April 2020 •Accepted: 26 Mei 2020 •Published online: 30 Juni 2020

\begin{abstract}
:
Dalam paper ini menjelaskan terkait penelitian yang telah dilakukan tentang pola asuh orangtua di Benda Kerep. Benda Kerep merupakan suatu kelompok masyarakat yang dikenal tradisional disalah satu daerah di Kota Cirebon. Dari Penelitian yang telah dilakukan didapatkan hasil bahwa dalam pola asuh orangtua di Benda Kerep didominasi oleh Ibu. Penelitian ini menggunakan pendekatan semi etnografi, dimana penelitian dilakukan selama 2 bulan dengan tinggal dengan kelompok masyarakat Benda Kerep. Untuk analisis sendiri menggunakan teknik grounded theory. Dari apa yang didapatkan dalam penelitian bahwa dalam kondisi saat ini yang modern masih ada kelompok masyarakat yang masih menjalani cara tradisional dengan tetap memperrtahankan konstruksi social dimana pengasuhan merupakan tanggung jawab Ibu.
\end{abstract}

Kata kunci: Ibu; pola asuh; dominasi

\begin{abstract}
This paper describes the research on parenting styles at Benda Kerep. Benda Kerep is a traditional community group in Cirebon city. From the research that has been done, it is found that the parenting style in Benda Kerep is dominated by mother. This study used a semi ethnographic approach, the study was conducted for 2 months living with the Benda Kerep community group. For the analysis itself using griunded theory techniques. From the research that in todays modern conditions there are still groups of people who still practice the traditional way while maintaining the social construction where care is the responsibility of the mother.
\end{abstract}

Keywords: mother; parenting; domination.

\footnotetext{
*Lutfatulatifah, Email: uul@syekhnurjati.ac.id
} 


\section{A. PENDAHULUAN}

Kelompok masyarakat Benda Kerep yang terletak di Argasunya Kecamatan Harjamukti Kota Cirebon dikenal taat pada nilai-nilai Islam dan masih memelihara tradisi yang masih dilakukan hingga sekarang. Tradisi tersebut dilakukan oleh masyarakatnya dengan maksimal hingga menarik simpati masyarakat yang ada di Cirebon dan luar Cirebon (Ruyadi, 2010). Tradisi yang dipertahankan oleh kelompok masyarakat Benda Kerep ini dapat dikatakan sebagai kearifan local (local wisdom) karena menjadikan acuan dalam hidup aturan-aturan dan nilai-nilai yang ada. Salah satu contohnya adalah adanya patronaise dari kyai dalam pendidikan pada anak-anak Benda Kerep.

Adat istiadat yang masih dilakukan kelompok masyarakat Benda Kerep tersebut tidak terlepas dari peran serta orangtua, dimana orangtua merupakan satu unit terpenting dalam masyarakat (Muchtar, 2009). Orangtua memiliki peran besar dalam melestarikan kebudaan yang ada dilingkungannya, karena orangtua menjadi tempat pertama anak belajar menjalani hidup bersosial belajar nilai dan norma. Pola asuh orangtua sering kali berkaitan dengan kedisiplinan dan kemandirian, namun pada masyarakat Benda Kerep pola asuh orangtua tersebut tampak pada ketaatannya pada nilai-nilai dasar tradisi seperti ketaatan pada wasiat sepuh dan menolak hal-hal yang bertentangan dengan ajaran Islam menjaga akhlak (Ruyadi, 2010).

Baumrind (Johnson, Welk, Saint-Maurice, \& Ihmels, 2012) sendiri merumuskan setidaknya empat teori pola asuh orangtua yakni otoritarian, otoritatif, permisif yang mengabaikan dan permisif yang menuruti. Dari ke empat teori tersebut Baumrind mengunggulkan salah satu bentuk pengasuhan. Orangtua akan memiliki kecenderungan pada salah satu bentuk pola asuh tertentu, meskipun cara pengasuhannya akan berbeda disetiap usia anak mengikuti kebutuhan dan kemampuan anak. Meskipun teori baumrind sendiri untuk konteks social yang berbeda mendapatkan hasil yang berbeda juga. Seperti untuk kelompok masyarakat asia yang dimana otoritatif justru mendapatkan hasil yang baik dibandingkan di Amerika negara asal penelitian Baumrind (Lestari, 2012).

Dalam konteks Indonesia sendiri termasuk dalam kelompok masyarakat kolektivis dibandingkan Amerika yang Individualis. Anak-anak Indonesia dilatih untuk mengembangkan atribut pribadi yang mendukung harmoni kelompok, rasa hormat kepada kepada otoritas, pengendalian emosi, dan kerjasama melalui sosialisasi yang 


\section{Lutfatulatifah}

mereka alami (Lutfatulatifah, Adriany, \& Romadhona, 2015). Pengasuhan anak yang dilakukan orangtua dipengaruhi oleh konteks budaya lingkungan tempat tinggal. Termasuk peran Ibu yang lebih dominan dalam pengasuhan juga merupakan bentuk pengaruh budaya masyarakatnya.

\section{B. METODOLOGI PENELITIAN}

Penelitian ini menggunakan pendekatan etnografi dan dilakukan selama dua bulan penuh sehingga tidak sepenuhnya etnografi secara waktu yang bisa dilakukan selama berbulan-bulan hingga bertahun-tahun (Ratna, 2010). Namun meskipun demikian peneliti tetap memperhatikan kaidah penelitian etnografi.

Fokus penelitian ini adalah pola asuh orangtua anak usia dini di Benda Kerep dengan setting alami (Sugiono, 2011). Mengamati interaksi orangtua dan anak di Benda Kerep dan mengikuti keseharian masyarakat di Benda Kerep dengan terlibat langsung dan merasakan kehidupan subjek yang diteliti. Membaur dalam kehidupan masyarakat sehari-hari dan mengobservasi dan mewawancara kelompok yang menjadi subjek penelitian.

Waktu dua bulan tentu tidak cukup untuk mengumpulkan data etnografi dan memahami makna kehidupan orangtua dalam mengasuh anaknya, sehingga peneliti menentukan informan kunci untuk membantu peneliti. Informan kunci ini adalah warga asli Benda Kerep yang sebelumnya peneliti sudah kenal sebelum melakukan penelitian. Hal ini tentu bisa dilakukan jika peneliti sudah memahami kondisi penelitian sebelumnya dan pemilihan informan ini bisa dilakukan selama masih anggota dari kelompok tersebut (Creswell, 2012).

Dalam prosedur penelitian etnografi analisis data tidak dilakukan diakhir setelah data terkumpul namun dilakukan setiap harinya setelah berinteraksi dengan masyarakat. Teknik analisis data dalam penelitian ini menggunakan grounded theory. Dimana peneliti tidak membutuhkan pengetahuan dan teori tentang objek penelitian untuk mensterilkan subjektivitas peneliti (Bungin, 2010). Dalam analisis data sendiri dilakukan dengan mengkoding yakni memebrikan nama terhadap masing baris data dari catatan lapangan, yang kemudian tahapan selanjutnya yakni fase selektif terfokus. Yakni mengklasifikasikan kode yang mirip kemudian menjadikannya sebuah tema-tema besar. Dan didapatkan sebuah tema besar terkait adanya dominasi peran Ibu dalam pengasuhan anak usia dini di Benda Kerep. 
Validasi dan realibitas dalam penelitian ini menggunakan dua cara yakni dengan mentriangulasi data. Dari Observasi, wawancara, juga pendapat tokoh masyarakat. Lalu cara yang kedua adalah dengan refleksivitas. Peneliti berusaha menanggalkan jubahnya sebagai peneliti juga sebagai orang luar yang berusaha beradaptasi dan melebur dengan masyarakat Benda Kerep.

\section{RESULT AND DISCUSSION}

Dalam praktik pengasuhan yang terjadi di Benda Kerep peneliti melihat seorang ibu lebih dominan dalam pengasuhan. Pengasuhan meliputi perawatan dan menjaga, serta praktik pengasuhan yang bersifat mendidik.

Dalam beberapa kesempatan peneliti sering menemukan bagaimana kaum ibu lebih mendominasi dalam praktik pengasuhan pada anak, terutama pada anak usia dini. Ibu memberikan asi, memberikan makan, memandikan anak, menggantikan popok, serta menemani bermain. Waktu anak lebih banyak dihabiskan bersama ibu dibandingkan dengan ayah mereka. Seorang ibu menjaga anaknya dengan terlibat bermain. Rata-rata ibu-ibu di Benda Kerep tidak memiliki pekerjaan tetap ataupun pergi berkebun dan hanya berada dirumah, namun apa bila ada hajat disalah satu warga maka para ibu akan membantu dan membawa serta anak-anak mereka dalam pekerjaan didapur.

Para pengobeng adalah orang benda kerep, kerabat, atau santrisantri yang membantu selama acara haolan mereka makan dan tinggal sementara di Kyai. Para pengobeng yang memiliki anak di ikut sertakan pula. Ketika anak-anak menangis orang tua akan meninggalkan sebentar pekerjaan mereka kemudian kembali lagi bekerja setelah anaknya tidak menangis atau tertidur. Ada juga yang menidurkan atau menyusui anakanaknya sembari tetap melakukan pekerjaan. (Catatan lapangan)

Meskipun ibu sibuk membantu pekerjaan hajat, ibu tidak begitu saja melepaskan untuk memberikan kebutuhan-kebutuhan anak. Jika anak membutuhkan sesuatu ibu meninggalkan sebentar pekerjaan mereka untuk menenangkan anak kemudian kembali bekerja. Kebanyakan masyarakat beranggapan bahwa perempuan lebih baik dirumah mengurusi rumah tangga sehingga pengasuhan anak menjadi tanggungjawab ibu sepenuhnya, sedangkan laki-laki bekerja keluar rumah untuk memenuhi kebutuhan rumah tangga. Kebanyakan warga masyarakat di Benda Kerep mencari nafkah dengan berdagang ke luar kota, disamping mereka juga memiliki kebun untuk memenuhi kebutuhan sehari-hari. 
Lutfatulatifah

Lestari (2012) menyatakan bahwa konsep perkawinan yang tradisional berlaku pembagian tugas dan peran suami istri. Disamping itu Papali, Olds, dan Feldman (2013) mengungkapkan bahwa perempuan diharapkan mendedikasikan waktu mereka untuk merawat rumah dan anak-anak, sedangkan laki-laki sebagai penyedia kebutuhan dan perlindungan. Barnard \& Martell (Santrock, 2007) juga menyatakan bahwa realitas peran ibu kini adalah bahwa di banyak keluarga, tanggung jawab utama atas anak maupun pekerjaan rumah tangga dan bentuk lainnya dari "pekerjaan keluarga" masih dibebankan dipundak ibu.

"saya pengen sekolah, tapi gak boleh sama bapak. Padahal saya bilang 'pak, mau sekolah sih, padu sampe smp bae.' Tapi bapaknya bilang 'buat apa, perempuan sih nanti juga kedapur ini.' Jadi ya udah gak sekolah, langsung mesantren." Ujar Anis. "Ang Yaya juga gak sekolah, anaknya kang Tio gada yang sekolah. Dulu mah sekolah sampe diharamkan. Banyaknya pesantren sampe ada orang tua yang anaknya masih 5 tahun juga dipesantrenin." (Catatan lapangan)

Dari kutipan diatas menunjukkan bahwa bagaimana pendapat seorang ayah pada anak perempuannya, tentang bagaimana seharusnya perempuan. Seorang perempuan selalu diidentikkan menjadi seseorang yang bersikap lemah lembut dan baiknya berada dirumah. Seorang ibu yang selalu dipandang dengan kelembutan dan bertanggungjawab penuh pada anak-anak mereka juga membangun sebuah kelekatan yakni terbentuknya emosi antara ibu dan anak. Emosi tersebut seperti sebuah penerimaan anak oleh ibunya dan kehangatan. Mercer (Lestari, 2012) mendefinisikan bahwa kelekatan yakni sebagai ikatan emosi yang terjadi diantara manusia yang memandu perasaan dan perilaku. Anak mengembangkan emosi mendalam dengan orang terdekat yang merawatnya dan sering berada dekat dengan anak secara terus menerus. Dalam bentuk pengasuhan terdapat sebuah dimensi kehangatan sebagai penerimaan anak oleh orang tua. Lestari (2012) dimensi kehangatan merupakan suatu rentang kontinum, yang di satu sisi ditandai oleh penerimaan yang mencakup berbagai perasaan dan perilaku yang menunjukkan kehangatan, afeksi, kepedulian, kenyamanan, perhatian, perawatan, dukungan, dan cinta. Dalam banyak kesempatan peneliti melihat bahwa seorang ibu disini memberikan dukungan serta keterlibatannya dalam banyak kegiatan anak. El-lis, Thomas, \& Rollins (Lestari, 2012) mendefinisikan dukungan sebagai interaksi yang dikembangkan oleh orang tua yang dicirikan oleh perawatan, kehangatan, persetujuan, dan berbagai perasaan positif orang tua terhadap anak. Meski peran ibu lebih dominan bukan berarti ayah tidak memiliki andil dalam pengasuhan anak. Pengasuhan anak yang dilakukan 


\section{Lutfatulatifah}

oleh ayah dalam bentuk bantuan penjagaan pada saat ibu tengah disibukkan dengan pekerjaan rumah lain dan pada saat ayah sedang ada di rumah.

Pengasuhan anak akan memberikan hasil yang lebih baik bila ayah dan ibu menjalankan pengasuhan bersama (co-parenting), yaitu bila orang tua bersikap saling mendukung dan bertindak sebagai satu tim yang bekerja sama, bukan saling bertentangan (Lestari, 2012). Lamb (Santrock, 2007) mengungkapkan bahwa ayah terlibat lebih banyak dalam permainan yang bersemangat, seperti bermain melemparlemparkan si bayi, mengayunayunkannya ke udara, menggelitik dan sebagainya. Peneliti melihat tidak banyak keterlibatan ayah dalam pengasuhan, hanya sebatas menggantikan menjaga anak dan tidak banyak terlibat dalam kegiatan bermain anak. Menurut informan kunci peneliti memperoleh informasi bahwa beberapa pasangan suami istri ada yang menetapkan aturan bahwa jika anak mereka terlahir perempuan maka ayah tidak akan terlibat banyak dalam pengasuhan anak, namun jika anak mereka terlahir laki-laki maka ayah akan ikut dalam kegiatan pengasuhan anak. Adanya pembagian kerja antara laki-laki dan perempuan mempengaruhi pengasuhan orang tua pada anaknya. Hal ini memberikan pengaruh pada anak dalam memperoleh identitas gendernya melalui interaksi dengan orang tuanya dan lingkungannya.

\section{CONCLUSION}

Dominasi peran ibu dalam pengasuhan anak di Benda Kerep tidak serta merta terjadi begitu saja. Namun juga hasil bentukan masyarakat yang melanggengkan hal tersebut. Ibu memiliki dominansi dalam pengasuhan pada anak. pembagian kerja antara Ibu dan Ayah masih menganut sistem tradisional dimana Ibu yang memiliki tanggung jawab penuh pada pekerjaan rumah dan pengasuhan anak serta pendidikan anak, sedangkan Ayah bertanggung jawab pada nafkah keluarga. Pengasuhan berdasarkan genderpun sangat kental di Benda Kerep. Dimana anak diperlakukan sesuai dengan jenis kelaminnya dan beberapa kesempatan untuk laki-laki dan perempuan berbeda. Misalkan untuk memperoleh pendidikan laki-laki lebih diutamakan diberi kesempatan untuk mengenyam pendidikan keluar aerah Benda Kerep sedangkan perempuan lebih diutamakan untuk berada dirumah atau memperoleh pendidikan pada kyai terdekat. 
Lutfatulatifah

UCAPAN TERIMAKASIH

Terimakasih pada Ibu Vina Adriany, Ph.D dan Ibu Dr. dr. Nur Faizah Romadhona, M.Kes. atas bimbingannya dalam menyelesaikan penelitian ini. Juga kelompok masyarakat Benda Kerep, Kang Miftah dan santri-santrinya.

\section{REFERENCES}

Bungin, B. (2010). Penelitian Kualitatif; Komunikasi, Ekonomi, Kebijakan Publik, dan Ilmu Sosial Lainnya. Jakarta: Kencana.

Creswell, J. (2012) Qualitative Inquiry \& Research Design: Choosing Among Five Approasches, Third Edition. California: SAGE Publicaion, Inc.

Johnson, R., Welk, G., Saint-Maurice, P. F., \& Ihmels, M. (2012). Parenting styles and home obesogenic environments. International Journal of Environmental Research and Public Health, 9(4), 1411-1426. https://doi.org/10.3390/ijerph9041411

Lestari, S. (2012). Psikologi Keluarga: Penanaman nilai dan penanganan konflik dalam keluarga. Jakarta:Kencana.

Lutfatulatifah, Adriany, V., \& Romadhona, N. F. (2015). Pola Asuh Orang Tua Anak Usia Dini di kampung Adat Benda Kerep Kota Cirebon. Jurnal Pendidikan Serantau, 1(1), 76-101.

Papalia, D.E., Olds, S.W., \& Feldman, R.D. (2013). Human Development: Perkembangan Manusia. (Buku 1, Edisi Kesepuluh) Jakarta : Salemba Humanika

Ratna, N.K. (2010). Metodologi Penelitian:Kajian Budaya dan Ilmu Sosial Humaniora Pada Umumnya. Jogjakarta: Pustaka Pelajar.

Ruyadi, Y. (2010). MODEL PENDIDIKAN KARAKTER BERBASIS KEARIFAN BUDAYA LOKAL (Penelitian terhadap Masyarakat Adat Kampung Benda Kerep Cirebon Provinsi Jawa Barat untuk Pengembangan Pendidikan Karakter di Sekolah). Proceedings of The 4th International Conference on Teacher Education; Join Conference UPI \& UPSI, (November), 8-10. Retrieved from http://file.upi.edu/Direktori/PROCEEDING/UPIUPSI/2010/Book_3/MODEL_PENDIDIKAN_KARAKTER_BERBASIS_KEARIFAN_BUD AYA_LOKAL_(Penelitian_terhadap_Masyarakat_Adat_Kampung_Benda_Kerep_Cireb on_Provinsi_Jawa_Barat_untuk_Pengembangan_Pendidikan_Karakter_di_Sekolah). Santrock, J.W. (2007). Perkembangan Anak. (Jilid 2, Edisi Kesebelas). Jakarta:Erlangga. Sugiono. (2011). Metode Penelitian Kuantitatif Kualitatif dan R\&D. Bandung:Alfabeta. 